\title{
Human Syngamosis as an Uncommon Cause of Chronic Cough
}

\author{
Janaína Oliveira Bentivi Pulcherio ${ }^{1}$ Eduardo Oliveira Machado da Silva ${ }^{1}$ Daniela Pereira Rezende ${ }^{1}$ \\ Patrícia Bittencourt Barcia Barbeira ${ }^{1}$ Rosane Siciliano Machado ${ }^{1}$ Marcos Aurélio Baptista de Oliveira ${ }^{1}$
}

${ }^{1}$ Department of Otorhinolaringology, Central Hospital of Military Police of Rio de Janeiro, Rio de Janeiro/RJ, Brazil

Int Arch Otorhinolaryngol 2013;17:413-414.
Address for correspondence Janaína Oliveira Bentivi Pulcherio, Department of Otorhinolaringology, Central Hospital of Military Police of Rio de Janeiro, Rua Estácio de Sá, número 20, Estácio, Rio de Janeiro/ RJ 20211-270, Brazil (e-mail: janabentivi.orl@gmail.com).

\begin{abstract}
Keywords

- cough

- parasites

- larynx
\end{abstract}

\section{Introduction}

The cough is symptom of a great variety of pulmonary and extrapulmonary diseases. It produces several alterations in the individual lifestyle; it is one of the most important causes of search for medical attention, and it may result in high costs on diagnostic exams and medications. ${ }^{1}$

The dry cough is difficult to diagnose and chronic cough (when it lasts longer than 8 weeks) is even a diagnostic challenge. ${ }^{1,2}$ Brazilian and international guidelines lead the investigation to the most common causes: asthma, reflux disease, and rhinopathies. ${ }^{1,3}$ Among several uncommon causes of chronic cough can be parasitism, through the pulmonary cycle or chronic parasitism of upper airways, a rare condition. ${ }^{2}$

We introduce the case of a patient who presented chronic cough due to parasitism of upper airways.

\section{Case Report}

A 41-year-old Caucasian Brazilian woman presented to our hospital with a chronic cough and a foreign body sensation in her throat for 5 months. She had no other symptoms. In this period she had visited many physicians and used several types of medication without improvement of her condition. There was no history of contact with birds, cattle, or even pets.

The physical examination showed no abnormalities. In the video laryngoscopy we observed a reddish vermiform organism with active movements, $\sim 15 \mathrm{~mm}$ in length. It had one end attached to the base of the epiglottis (-Fig. 1).

The organism was removed by direct laryngoscopy. It was a Y-shaped worm. The material was sent to biological analysis. It was identified as a couple of Mammomonogamus (Syngamus) laryngeus, a nematode from Syngamidae family.

At the 30-day follow-up appointment, the patient had no symptoms. A new laryngoscopy exam was performed and was normal (-Fig. 2).

\section{Discussion}

Nematodes of the family Syngamidae parasitize the upper respiratory tract of cattle, buffaloes, goats, and wild and domestic birds. Humans can be accidentally infected. ${ }^{4,5}$ received

December 28, 2012

accepted

February 20, 2013
Copyright ( 2013 by Thieme Publicações DOI http://dx.doi.org/ Ltda, Rio de Janeiro, Brazil 10.1055/s-0033-1351680. ISSN 1809-9777. 


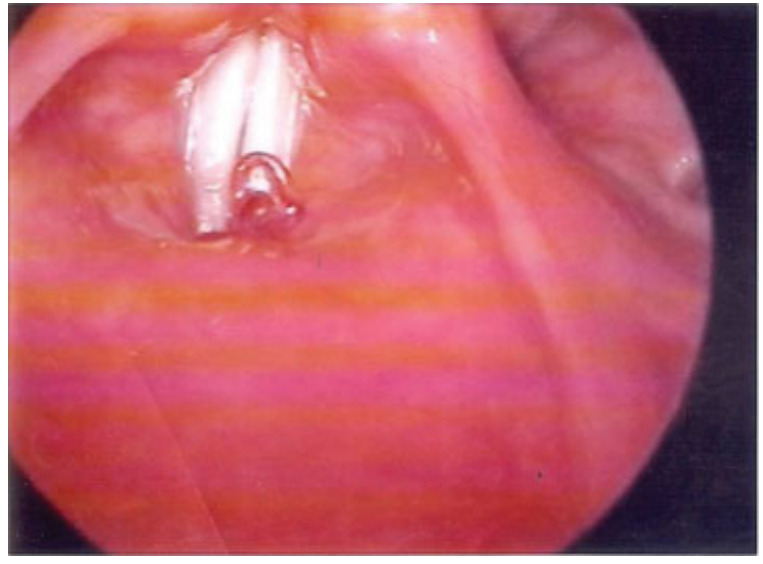

Fig. 1 Video laryngoscopy showing a vermiform organism on the larynx.

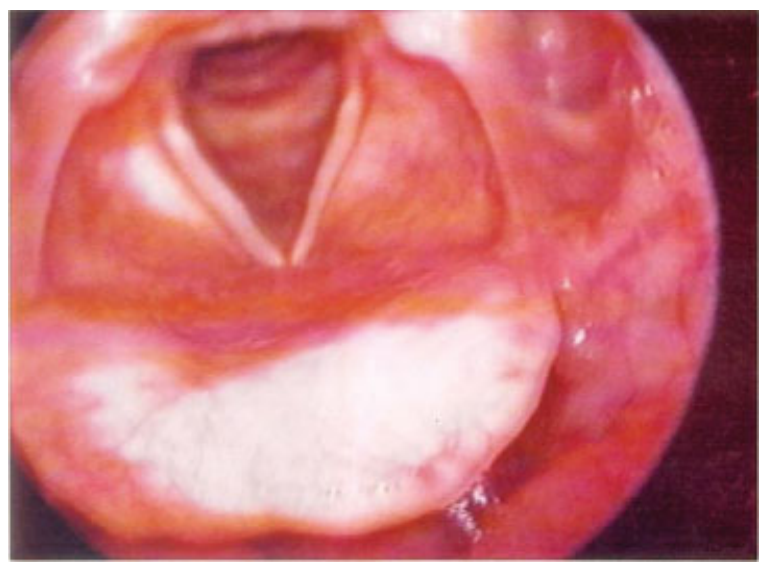

Fig. 2 Video laryngoscopy after treatment.

The species Syngamus laryngeus (Mammomonogamus laryngeus) was first demonstrated in 1899 by Railliet. The first case of human disease caused by this organism was reported in 1913 by Leiper in the West Indies. In Brazil, Travassos described the first case of human disease in Salvador (state of Bahia) in $1921.4,6$ There are $\sim 100$ cases of human infection, and almost all of them were originated in the Caribbean Islands and Brazil. ${ }^{5,6}$

S. laryngeus is a reddish nematode found in couple, in permanent copula, which is why the pair appears as a Y. The female measures 8 to $23 \mathrm{~mm}$ and the male measures 3 to $6 \mathrm{~mm} \cdot{ }^{6,7}$ The life cycle of the parasite includes the elimination of eggs in the soil by coughing or by the stool (when they are swallowed). These eggs hatch and release larvae, which infect animals through contaminated water and food. ${ }^{7,8}$ Humans are parasitized at this same way, and the worms develop themselves in larynx or trachea, causing laryngotracheal irritation that results in cough with or without hemoptysis and bronchospasm. It is not clear if these parasites migrate from pharynx to the larynx or if they lodge in the airways after going through the gastrointestinal tract/bloodstream/lung/ larynx cycle., ${ }^{5,8}$

The blood cell count does not reveal relevant eosinophilia., ${ }^{4,7}$ The diagnosis is usually made when the worms are expelled during an episode of cough or when visualized in an endoscopic exam. ${ }^{5,7}$

The treatment consists in the removal of the worm and it is the only effective approach. Some studies report the use of mebendazole and thiabendazole, with favorable outcome.,

\section{Conclusion}

Otolaryngologic causes must be considered in initial management of patients with chronic dry cough after you can eliminate the most common diagnoses. The endoscopic exam of the larynx is easy to perform and is essential in differential diagnosis of a great variety of diseases that curses with chronic cough including parasitism of upper airways. This is a rare entity but must be considered in Brazil where many cases where described.

\section{References}

1 II Diretrizes Brasileiras no Manejo da Tosse Crônica. J Bras Pneumol 2006;32(6 Suppl):403-446

2 Neto FXP, Ramos CF, Silva AMT, Santos KAN, Azevedo ACG, Palheta ACP. Tosse Crônica na Rotina Otorrinolaringológica. Int Arq Otorrinolaringol 2011;15:231-240

3 Irwin RS, Baumann MH, Bolser DC, et al; American College of Chest Physicians (ACCP). Diagnosis and management of cough executive summary: ACCP evidence-based clinical practice guidelines. Chest 2006;129(1, Suppl):1S-23S

4 Weinstein L, Molavi A. Syngamus laryngeus infection (syngamosis) with chronic cough. Ann Intern Med 1971;74:577-580

5 Rosen MJ. Chronic cough due to tuberculosis and other infections: ACCP evidence-based clinical practice guidelines. Chest 2006;129 (1, Suppl):197S-201S

6 Freitas AL, De Carli G, Blankenhein MH. Mammomanogamus (Syngamus) laryngeus infection: a new Brazilian human case. Rev Inst Med Trop Sao Paulo 1995;37:177-179

7 Marinho AC, Tavares W. Rotinas de diagnóstico e tratamento das doenças infecciosas e parasitárias. 2 ed. Rio de Janeiro, Brazil: Atheneu; 2007

8 Pontes P, Gadelha ME, Gregório LC, Behlau M, Steffen N. Singamose laríngea: apresentação de dois casos. Braz J Otorhinolaryngol 1992;58:294-297 